\title{
FAKTOR PENYEBAB PENYIMPANGAN TATA RUANG PEMBANGUNAN KONDOMINIUM DI KOTA BANDUNG
}

\author{
Agri Chairunisa Isradjuningtias \\ Junior Legal Kantor Hukum \\ email: agri_chairunisa@yahoo.com
}

disampaikan 5/9/17 - di-review 27/11/17 - diterima 25/12/17

DOI: $10.25123 /$ vej. 2687

\begin{abstract}
The Bandung Townhall apparently believed that development of housing apartments (condominium) is the perfect solution to meet housing need of increasing urban population. However, quite a number of condominiums are constructed disregarding spatial or land use planning or building regulations. By using a socio-legal approach, the author attempts highlights a number of influencing factors explaining the violation of prevailing laws and regulations pertaining to land use, spatial planning as well as building regulations.
\end{abstract}

Keywords:

spatial plan; condominiums; compliance theory; Urban Spatial Plan Regulation.

\begin{abstract}
Abstrak
Pemerintah Kota kiranya percaya bahwa pembangunan kondominium adalah jawaban bagi permasalahan penyediaan dan pemenuhan kebutuhan tempat tinggal masyarakat kota, juga di Kota Bandung. Namun kerap terjadi pembangunan kondominium menyalahi peraturan perundang-undangan yang terkait dengan tata ruang, pemanfaatan tanah maupun aturan bangunan. Metoda sosio-legal digunakan untuk mengungkap faktor-faktor yang menyebabkan penyimpangan peraturan-peraturan terkait.
\end{abstract}

Kata kunci: tata ruang; kondominium; teori kepatuhan; RTRWK.

\section{Pendahuluan}

Penelitian ini akan mengobservasi terjadinya penyimpangan tata ruang dengan studi kasus pembangunan kondominium ${ }^{1}$ yang terdapat di kota Bandung.

\footnotetext{
1 Condominium menurut arti kata berasal dari bahasa Latin yang terdiri dari dua kata, yaitu: 'con' yang berarti bersama-sama dan 'dominium' yang berarti pemilikan. Dalam perkembangan selanjutnya, kondominium mempunyai arti sebagai suatu pemilikan bangunan yang terdiri atas bagian-bagian yang masing-masing merupakan suatu kesatuan yang dapat digunakan dan dihuni secara terpisah, serta dimiiki secara individual berikut bagian-bagian lain dari bangunan itu dan tanah di atas mana bangunan itu terdiri yang karena fungsinya digunakan bersama, dimiliki secara bersama-sama oleh pemilik bagian yang dimiliki secara individual tersebut di atas. Dalam Arie S. Hutagalung, Sistem Kondominium Indonesia: Implikasi dan Manfaatnya bagi Developer/Properti Owner. (Makalah Program Pendidikan Lanjutan Ilmu Hukum Bidang Konsultan Hukum dan Kepengacaraan, FH-UI), Jakarta, hlm.1.

Menurut Black's Law Dictionary, "Condominium: system of separate ownership of individual units in multiple-unit building”. Susskind v.1136 Tenants Corp., 251 N.Y.S.2sd 321, 327,43 Misc.2d 588.
} 
Penelitian terfokus untuk menyelidiki faktor-faktor yang mempengaruhi penyimpangan tata ruang kota Bandung.

Kecenderungan penyimpangan terhadap tata ruang yang telah ditetapkan dapat disebabkan oleh berbagai faktor baik produk tata ruang maupun pada tahapan implementasi. Pemantauan dalam bentuk penelitian terhadap tata ruang sangat diperlukan untuk meneliti apakah produk hukum rencana tata ruang tersebut berjalan sesuai dengan pemanfaatannya atau telah terjadi penyimpangan dan faktor apa yang mempengaruhi terjadinya penyimpangan tersebut. ${ }^{2}$ Melalui metode sosio-legal ${ }^{3}$ yaitu kajian terhadap hukum dengan menggunakan pendekatan ilmu hukum maupun ilmu-ilmu sosial. Menurut Irianto sosio-legal lebih dari studi hukum empirik, karena ahli sosio-legal juga harus memiliki pemahaman dan kemampuan analisis mengenai peraturan perundang-undangan, instrumen, dan substansi hukum yang terkait dengan penelitian. ${ }^{4}$

Pada dasarnya pemikiran sosio-legal menambahkan (perspektif yang lain) dalam mempertimbangkan proses pembentukan legislasi, penerapan hukum dan penyelesaian sengketa. ${ }^{5}$ Pada penelitian dilakukan dengan cara pemetaan data dihimpun, diolah, dan dianalisis untuk mengetahui faktor yang menjadi penyebab

Henry Campbell Black, M.A, Black's Law Dictionary, Revised Fourth Edition by Publisher's Editorial Staff, ST. Paul, Minn, West Publishing Co, 1968, hlm. 367

Menurut Kamus Besar Bahasa Indonesia (KBBI) kondominium /kon-do-mi-ni-um/ n apartemen mewah. Dalam Pusat Bahasa Departemen Pendidikan Nasional, Kamus Bahasa Indonesia, Jakarta, 2008, hlm.746.

2 Zubair Butudoka, Evaluasi Pemanfaatan Ruang dan Struktur Tata Ruang Wilayah Kabupaten Tolitoli, SMARTek, http://download.portalgaruda.org/article.php?article=10630\&val=750, terakhir diunduh pada tanggal 7 Agustus 2017.

3 Menurut Prof.Arief Sidharta (dalam Pendidikan Sosio-Legal di Fakultas Hukum Universitas Lampung, Bandar Lampung 13 Juni 2014) "Sosio-Legal, bukanlah sosiologi hukum, bukan pula direduksi menjadi semata penelitian [yuridis]- empiris, sosio-legal mensyaratkan kemampuan penelitian hukum normatif secara baik", sebagaimana dikutip oleh Herlambang P. Wiratraman dalam "Penelitian Sosio-Legal dan Konsekuensi Metodologisnya", hlm.4.

https://herlambangperdana.files.wordpress.com/2008/06/penelitian-sosio-legal-dalam-tun.pdf terakhir diunduh pada tanggal 19 Juni 2017.

4 Candra Kusuma, Penelitian Interdisipliner Tentang Hukum, Seri Hukum dan Keadilan Sosial, Epistema Institute, Depok, 2013, hlm.80

5 Sulistiowati Irianto, Jan Michele Otto, Sebastiaan Pompe, Adriaan W. Bedner, Jacqueline Vel, Suzan Stoler, dan Julia Arnscheidt, Kajian Sosio-Legal, Seri Unsur-Unsur Penyusun Bangunan Negara Hukum, Penerjemah Tristam Moelyono, Pustaka Larasan, Jakarta: Universitas Indonesia, Universitas Leiden, Universitas Groningen, 2012, hlm.vii 
penyimpangan tata ruang di kota Bandung khususnya pada pembangunan kondominium.

Penelitian hukum ini disajikan dalam bentuk observasi letak pembangunan kondominium di kota Bandung apakah sesuai dengan Rencana Tata Ruang Wilayah kota Bandung tahun 2011-2031 (selanjutnya disingkat dengan RTRW kota Bandung). Penataan ruang wilayah bertujuan untuk tercapainya pemanfaatan ruang yang berkualitas. Untuk itu, diperlukan pengendalian melalui kegiatan pengawasan dan penertiban terhadap pemanfaatan ruang, sebagaimana yang diamanatkan dalam Undang-Undang Nomor 26 Tahun 2007 tentang Penataan Ruang, bahwa pengawasan terhadap pemanfaatan ruang diselenggarakan dalam bentuk pelaporan, pemantauan dan evaluasi yang dapat dilakukan oleh Pemerintah atau Pemerintah Daerah serta peran serta masyarakat. 6

Melalui kegiatan pemantauan dan evaluasi, kesesuaian pemanfaatan ruang sesuai dengan fungsi yang telah ditetapkan dapat diwujudkan. Menurut M. Daud Silalahi, suatu ruang tertentu dapat digunakan untuk berbagai alternatif kegiatan, seperti pemukiman, industri, pertanian, dan sebagainya. Apabila suatu kegiatan tertentu telah dilakukan di suatu ruang tertentu, pada waktu yang sama tidak dapat dilakukan suatu kegiatan yang lain karena dapat menimbulkan persaingan bahkan konflik dalam pemanfaatan ruang. ${ }^{7}$

Penataan ruang menggariskan bahwa pelaksanaan pembangunan di tingkat pusat maupun di tingkat daerah harus sesuai dengan rencana tata ruang yang telah ditetapkan. Dengan demikian pemanfaatan ruang termasuk di dalamnya struktur ruang selayaknya disesuaikan dengan rencana tata ruang. Kecenderungan penyimpangan tersebut dapat terjadi karena pada saat penyusunan produk rencana tata ruang kurang memperhatikan aspek-aspek

${ }^{6}$ Undang-Undang RI Nomor 26 Tahun 2007 tentang Penataan Ruang, L.N.R.I. Tahun 2007 Nomor 68, Pasal 55.

Dalam Pasal 1 angka 12, yang dimaksud dengan Pengawasan penataan ruang adalah upaya agar penyelenggaraan penataan ruang dapat diwujudkan sesuai dengan ketentuan peraturan perundang-undangan.

7 M. Daud Silalahi, Hukum Lingkungan Dalam Sistem Penegakan Hukum Lingkungan Indonesia, Alumni, Bandung, 2001, hlm.85. 
pelaksanaan pemanfaatan ruang atau sebaliknya bahwa pemanfaatan ruang kurang memperhatikan rencana tata ruang yang telah disusun. ${ }^{8}$ Oleh sebab itu, penting untuk mengadakan penelitian terkait faktor yang mempengaruhi penyimpangan tata ruang di kota Bandung.

Penelitian dilaksanakan dengan terlebih dahulu membandingkan penggunaan tata ruang wilayah dalam RTRW kota Bandung tahun 2011-2031 dan implementasinya. Setelah membandingkan penggunaan wilayah tata ruang pembangunan akan disajikan data harga per-unit dari kondominium di Kota Bandung dengan maksud untuk mengetahui harga rata-rata kondominium di kota Bandung dan menyajikan data pendapatan per kapita penduduk kota Bandung ${ }^{9}$ agar mendapatkan penjelasan lebih terperinci mengenai siapa yang menjadi konsumen dari kondominium di kota Bandung.

Setelah mengadakan perbandingan antara pendapatan per-kapita dari penduduk kota Bandung dan harga per-unit dari kondominium diharapkan akan mendapatkan jawaban dari permasalahan yaitu apakah faktor apa yang mempengaruhi penyimpangan tata ruang di Kota Bandung dengan studi kasus pembangunan kondominium, karena pada akhirnya data tentang siapa yang menjadi konsumen kondominium akan menjawab faktor pasar atau ekonomi yang mempengaruhi penyimpangan tata ruang.

Penyimpangan penataan ruang ini menarik untuk ditelusuri dan diadakan penelitian lebih lanjut karena penulis mendapatkan keterangan dari seorang yang merupakan salah satu pihak yang terganggung dengan adanya pembangunan kondominium yang berjarak 4 meter saja dari tempat tinggalnya. Menurut pengakuan beliau bahwa pembangunan kondominium di sebelah rumahnya itu

\footnotetext{
8 Zubair Butudoka, Supranote 2, hlm.245-246.

${ }_{9}$ Menurut Dumairy (1999) Pendapatan per Kapita (Per Capita Income/ PCI) adalah pendapatan rata-rata untuk masing-masing penduduk dalam satu periode tertentu. Penghitungan pendapatan per kapita adalah pendapatan nasional dibagi dengan jumlah penduduk dalam sebuah negara. Hal tersebut sebagaimana dikutip oleh Siska Lestari, Vecky A.J Masinambow, dan Mauna Th. B Maramis, Pengaruh Jumlah Penduduk dan Pendapatan Perkapita Terhadap Penerimaan Pajak Restoran di Kota Manado, Jurnal Berkala Ilmiah Efisiensi, Volume 16 No. 02 Tahun 2016, Fakultas Ekonomi dan Bisnis, Universitas Sam Ratulangi Manado, hlm.309. https://ejournal.unsrat.ac.id/index.php/jbie/article/viewFile/12404/11977 terakhir di unduh pada tanggal 30 Agustus 2017.
} 
kurang sesuai dengan peraturan yang berlaku tentang penataan ruang di kota Bandung.

Pembangunan kondominium yang berada di sebelah rumah penduduk itu bernama La Grande Merdeka Tamansari, yang merupakan salah satu kondominium yang didirikan di kawasan jalan Merdeka dan jalan Aceh. Apabila menelaah ketentuan dalam Rencana Tata Ruang Wilayah Kota Bandung tahun 2011-2031 jalan Merdeka diperuntukan untuk kawasan pusat perbelanjaan bukan untuk kawasan penghunian. Sehingga letak kondominium La grande ini dapat diindikasikan telah menyimpangi tata ruang Kota Bandung.

Berdasarkan contoh kasus dari seorang tersebut sebagai data awal membuat penulis tertarik untuk menelti lebih lanjut apakah telah terjadi penyimpangan dari apa yang telah ditetapkan oleh pemerintah dalam Rencana Tata Ruang Wilayah dan faktor apa yang menyebabkan penyimpangan tata ruang.

Penyimpangan tata ruang tidak hanya sekedar penyimpangan semata tetapi akibatnya meluas kepada beberapa aspek terkait lainnya. Keberadaan ruang sangat mempengaruhi kelangsungan hidup manusia, oleh sebab itu dalam melakukan perencanaan wilayah pemanfaatan dan pengelolaan ruang harus sebijaksana mungkin sehingga keharmonisan dapat terwujud guna mendukung proses pembangunan. Pembangunan yang dimaksud tidak hanya sekedar mengadakan pembangunan, namun pada hakekat pembangunan berkelanjutan yang berwawasan lingkungan (sustainable development).

Pemasalahan yang menyebabkan penyimpangan tata ruang di kota Bandung ini menarik untuk dianalisa, untuk mengetahui faktor penyebab penyimpangan tata ruang dan selanjutnya memberi masukan untuk mendorong pemanfaatan ruang ke arah yang lebih baik.

Pemasalahan penyimpangan erat kaitannya dengan kepatuhan. Pada penelitian ini dipilih satu teori yang paling berkaitan dengan kepatuhan hukum yaitu teori kepatuhan (compliance theory). Menurut Tom R. Tyler terdapat dua perspektif dasar kepatuhan pada hukum, yaitu instrumental dan normatif. Perspektif instrumental berarti individu dengan kepentingan pribadi dan tanggapan terhadap perubahan yang berhubungan dengan perilaku. Perspektif 
normatif berhubungan dengan moral dan berlawanan dengan kepentingan pribadi. ${ }^{10}$

Teori kepatuhan dari Tyler ini dianggap teori yang paling tepat untuk dijadikan pisau analisis dalam melakukan penelitian terkait dengan penyimpangan tata ruang kota Bandung, karena apabila terjadi penyimpangan maka terjadi ketidakpatuhan dari yang seharusnya. Selanjutnya diteliti pada bagian mana terdapat ketidakpatuhan yang mengakibatkan terjadinya penyimpangan tata ruang di kota Bandung khususnya pada pembangunan kondominium. Oleh karena itu, penelitian ini bertujuan tidak hanya untuk melihat dan menemukan faktor penyebab penyimpangan tata ruang, namun juga menemukan penyebab pangkal permasalahan dan memberikan solusi untuk memecahkan masalah.

\section{Pembahasan}

Indonesia sebagai negara berkembang dewasa ini sedang berupaya menyetarakan diri dengan negara-negara yang dianggap lebih maju dari Indonesia di segala bidang. Upaya ini dilakukan tentunya agar Indonesia menjadi negara yang lebih maju dari sebelumnya dan tidak tertinggal di era globalisasi saat ini. Salah satu upaya yang dilakukan oleh Indonesia di antaranya melakukan pembangunan di bidang ekonomi, struktur dan infrastruktur.

Pembangunan rumah susun merupakan salah satu alternatif pemenuhan kebutuhan masyarakat akan pemecahan masalah perumahan dan pemukiman di daerah perkotaan yang pertumbuhannya makin meningkat. Pembangunan rumah susun dianggap mampu meminimalisir penggunaan ruang. Pembangunan perumahan yang demikian itu sesuai dengan kebutuhan masyarakat terutama masyarakat perkotaan dengan mempergunakan sistem kondominium. ${ }^{11}$

Landasan hukum kondominium di Indonesia tunduk pada pengaturan tentang rumah susun yaitu Undang-Undang Nomor 16 tahun 1985 tentang Rumah Susun

\footnotetext{
${ }^{10}$ Rahmat Saleh, Studi Empiris Ketepatan Waktu Pelaporan Keuangan Perusahaan Manufaktur di Bursa Efek Jakarta, Simposium Nasional Akuntansi VII, Bali. p : 897-910, 2004, hlm.2-3

11 Arie S.Hutagalung, Supra no 1.
} 
LN 1985/75; TLN No. 3318 dan dilengkapi dengan Peraturan Pemerintah Nomor 4 tahun 1988 tentang Rumah Susun. Pada saat ditetapkan UU No. 16 tahun 1985 tentang Rumah Susun, pembangunan rumah susun ditujukan untuk memenuhi kebutuhan perumahan yang layak bagi masyarakat terutama untuk golongan masyarakat berpenghasilan rendah. ${ }^{12}$

UU No. 16 tahun 1985 tentang Rumah Susun dalam perkembangannya dianggap sudah tidak sesuai dengan perkembangan hukum, kebutuhan setiap orang, dan partisipasi masyarakat serta tanggung jawab dan kewajiban negara dalam penyelenggaraan rumah susun sehingga UU No. 16 tahun 1985 tentang Rumah Susun diganti dengan Undang-Undang Nomor 20 Tahun 2011 tentang Rumah Susun L.N.R.I Tahun 2011 Nomor 108 (selanjutnya disingkat dengan UURusun). ${ }^{13}$

Pada mulanya konsep rumah susun dibuat untuk memenuhi usaha pemerataan pemenuhan kebutuhan pokok tempat tinggal dengan peningkatan usaha-usaha penyediaan tempat tinggal yang layak, dengan harga yang terjangkau khususnya masyarakat yang mempunyai penghasilan rendah. Tetapi dewasa ini konsep tersebut mulai bergeser tidak hanya masyarakat yang tergolong berpenghasilan rendah. Kini konsep rumah susun diperluas maknanya sehingga terdapat rumah susun komersial yang dibuat dengan mewah untuk memenuhi kebutuhan masyarakat berpenghasilan menengah ke atas (selanjutnya dalam pengaturan UU Rusun disebut dengan rumah susun komersial) yang akrab dikenal dengan kondominium.

Bagi pengembang kondominium seharusnya dalam melakukan pembangunan tidak hanya kebutuhan akan pemukiman saja yang diperhatikan,

\footnotetext{
${ }^{12}$ Hal ini dipertegas dalam konsideran UU No. 16 Tahun 1985 tentang Rumah Susun, bahwa untuk mewujudkan kesejahteraan umum dan peningkatan taraf hidup rakyat, khususnya dalam usaha pemerataan pemenuhan kebutuhan pokok akan pemenuhan sebagaimana diamanatkan dalam Garis-garis Besar Haluan Negara, diperlukan peningkatan usaha-usaha penyediaan perumahan yang layak, dengan harga yang dapat dijangkau oleh daya beli rakyat terutama golongan masyarakat yang mempunyai penghasilan rendah.

${ }^{13}$ Dalam konsideran huruf e, Undang-Undang Nomor 20 Tahun 2011 tentang Rumah Susun L.N.R.I Tahun 2011 Nomor 108 selanjutnya dalam Pasal 1 angka 10, Kondominium dapat ditemukan pengaturannya dengan disebut Rumah Susun Komersial, yang definisinya adalah "rumah susun yang diselenggarakan untuk mendapatkan keuntungan."
} 
namun juga memperhatikan lingkungan hidup yang baik dan sehat. Pada dasarnya lingkungan hidup yang baik dan sehat merupakan hak asasi setiap warga negara Indonesia sebagaimana diamanatkan dalam Pasal 28H UUD 1945. ${ }^{14}$ Ketentuan UUD 1945 Pasal 28H diberlakukan dalam rangka pelaksanaan pembangunan ekonomi nasional dan diselenggarakan berdasarkan prinsip pembangunan berkelanjutan dan berwawasan lingkungan ${ }^{15}$ (sustainable development), agar lingkungan hidup di Indonesia tetap menjadi sumber daya dan penunjang hidup bagi rakyat Indonesia serta makhluk hidup lain.

Dalam hal rencana tata ruang kiranya Pemerintah telah menyadari bahwa perencanaan itu mahal, namun lebih mahal lagi adalah pembangunan tanpa perencanaan. ${ }^{16}$ Perencanaan adalah suatu bentuk kebijaksanaan, sehingga dapat dikatakan bahwa perencanaan adalah sebuah species dari genus kebijaksanaan. ${ }^{17}$ Masalah perencanaan terkait erat dengan perihal pengambilan keputusan serta pelaksanaannya. Perencanaan berperan sebagai pemecahan masalah yang saling terkait serta berpedoman kepada masa depan. ${ }^{18}$

Menurut Asep Warlan Yusuf tidak ada konsensus mengenai definisi atau teori perencanaan. Teori perencanaan dikembangkan dari penggabungan konsepkonsep yang berasal dari macam-macam disiplin ilmu. Teori perencanaan berkaitan dengan definisi tentang bentuknya, tahapannya, hubungannya dengan

14 UUD 1945 amandemen ke-empat, Pasal $28 \mathrm{H}$

(1) Setiap orang berhak hidup sejahtera lahir dan batin, bertempat tinggal, dan mendapatkan lingkungan hidup yang baik dan sehat serta berhak memperoleh pelayanan kesehatan.

(2) Setiap orang berhak mendapat kemudahan dan perlakuan khusus untuk memperoleh kesempatan dan manfaat yang sama guna mencapai persamaan dan keadilan.

(3) Setiap orang berhak atas jaminan sosial yang memungkinkan pengembangan dirinya secara utuh sebagai manusia yang bermartabat.

(4) Setiap orang berhak mempunyai hak milik pribadi dan hak milik tersebut tidak boleh diambil alih secara sewenang-wenang oleh siapa pun.

15 Undang-Undang RI Nomor 32 tahun 2009 tentang Perlindungan dan Pengelolaan Lingkungan

Hidup, L.N.R.I, Tahun 2009 Nomor 140, dalam konsideran (selanjutnya disingkat dengan UUPPLH)

16 Juniarso Ridwan dan Achmad Sodik, Hukum Tata Ruang Dalam Konsep Kebijakan Otonomi

Daerah, Nuansa, Bandung, 2007, hlm. 25.

17 Id.

18 Id. 
konteks proses perencanaan dan keluarannya. ${ }^{19}$ Adapun kriteria minimal dari suatu perencanaan adalah bahwa perencanaan itu harus merupakan kegiatan pemerintah beserta masyarakat untuk menetapkan metode-metode yang rasional dan strategis, berorientasi dan mengantisipasi masa depan, untuk memecahkan masalah-masalah, tidak rutin, yang diusahakan dengan sungguh-sungguh, dan berorientasi pada kegiatan. ${ }^{20}$

Saat ini pembangunan di Indonesia khususnya di wilayah Kota Bandung semakin berkembang dengan pesat. Bandung terkenal dengan keasrian kota, pusat perbelanjaan modern, dan tempat pariwisata. Hal ini menjadikan Kota Bandung sebagai salah satu kota yang menarik bukan sekedar dikunjungi tapi juga untuk tempat tinggal dan mencari pekerjaan. Berkaitan dengan hal tersebut Kota Bandung mengadakan pembangunan untuk memfasilitasi permintaan dan kebutuhan masyarakat. Terdapat banyaknya pembangunan gedung, pembangunan kondominium, dan hotel. Perkembangan pembangunan di Kota Bandung, perlu mendapat perhatian secara khusus dan mendalam dari akibat yang akan dan/atau mungkin saja terjadi pada lingkungan, serta perlu adanya perhatian akan keberlangsungan lingkungan serta harmonisasi antara lingkungan hidup dan makhluk hidup yang tinggal di dalam dan sekitarnya.

Perkembangan perubahan bentuk dan penggunaan rumah susun, menimbulkan adanya konsekuensi dalam kelanjutan hidup bersama dalam rumah susun. Sebelum melaksanakan suatu pembangunan penting diperhatikan adanya kajian guna bangunan dan analisa secara kritis terhadap efek yang timbul pada lingkungan hidup. Kajian tersebut adalah Analisis Mengenai Dampak Lingkungan (selanjutnya disingkat dengan Amdal). Amdal merupakan kajian mengenai dampak penting suatu Usaha dan/atau Kegiatan yang direncanakan pada

\footnotetext{
${ }^{19}$ Asep Warlan Yusuf, Wewenang Pemerintah Dalam Penataan Ruang (Suatu Model Pendekatan Sistem), Disertasi, Universitas Indonesia, Fakultas Hukum Program Pascasarjana, Jakarta, 2002, hlm. 115.

${ }^{20}$ Id. Lebih lanjut di jelaskan oleh Asep Warlan Yusuf bahwa dalam pengertian yang lebih sederhana, dalam perencanaan terkandung uncur-unsur sebagai berikut: (1) Masalah-masalah masa depan; (2) Persangkut-pautan antar masalah-masalah dan antara aktivitas sekarang dengan aktivitas masa depan; (3) Upaya pengemudian atau pengendalian (stuuren) masa depan dengan seluruh masalahnya.
} 
lingkungan hidup yang diperlukan bagi proses pengambilan keputusan tentang penyelenggaraan Usaha dan/atau Kegiatan. ${ }^{21}$

Memperhatikan Amdal pada dasarnya berkaitan dengan pemenuhan hak asasi masyarakat sekitar yang tentunya terkena dampak dari pembangunan. Masyarakat tidak hanya merupakan pihak yang mendapatkan manfaat dari penataan ruang namun juga merupakan pihak yang memiliki andil terhadap penataan ruang wilayahnya. Dalam hal ini masyarakat memiliki hak dan kewajiban untuk menentukan kualitas ruang yang ditinggalinya. ${ }^{22}$

Pembangunan kondominium marak dilakukan dengan mempertimbangkan keefektivitasan penggunaan ruang. Bangunan dididirikan secara vertikal sehingga dapat memenuhi kebutuhan lebih banyak masyarakat, dalam hal ini pangsa pasar kondominium yaitu masyarakat dengan penghasilan menengah ke atas. Demi merealisasikan rencana pembangunan tidak jarang dalam tahap pembangunan menimbulkan kontroversi di lingkungan masyarakat terkait dengan kepatuhan pelaksana pembangunan kondominium terhadap peraturan terkait dan pemenuhan hak kepada masyarakat sekitar yang terkena dampak dari pembangunan kondominium.

Pada permulaan abad ke-20 Richard M.Hurd (1903) mulai menyinggung masalah nilai tanah (land values), sewa (rents) dan biaya (costs) di dalam suatu kota yang dianggap mempunyai kaitan erat dengan pola penggunaan lahan. Dalam hal ini Hurd mengatakan bahwa "the patterns of land uses and land values will be mutually determining" (Hurd, 1924) dalam Carter (1975). ${ }^{23}$

Dalam pernyataannya sarjana ini mulai dengan prinsip bahwa: (1) "value in urban land, as in agricultural-land is the resultant of economic or ground rent capitalized". (2) "in cities, economic rent is based on superiority of location-only the sole function of city land being to furnish an area on which in erect buildings". Dengan berkembangnya area perkotaan ke arah luar maka variabel lokasi menjadi sedemikian penting sehingga sewa untuk tempat-tempat yang mempunyai

\footnotetext{
21 Peraturan Pemerintah RI Nomor 27 Tahun 2012 tentang Izin Lingkungan, L.N.R.I Tahun 2012 Nomor 48, Pasal 1 angka 2

22 Rencana Tata Ruang Wilayah (RTRW) Kota Bandung 2011-2031

${ }^{23}$ Hadi Sabari Yunus, Struktur Tata Ruang Kota, Pustaka Pelajar, Yogyakarta, 1999, hlm.63
} 
aksesbilitas yang tinggi akan meningkat pula. Akibatnya pada lahan-lahan perkotaan akan terjadi persaingan ketat untuk mendapatkan lokasi-lokasi seperti itu, seperti dikatakan dalam karyanya bahwa (3) any utility may compete for any location within a city and all land goes to the highest bidder. Di sini nampak bahwa penggunaan lahan yang mampu menawar paling tinggilah yang akan mendapatkan tempat yang diinginkan. Berdasarkan kenyataan ini Hurd menyimpulkan pendapatnya sebagai berikut (4) since value depends on economic rent and rent on location on conviniece, and convinience on nearness, we may eliminate the intermediate steps and say that value depends on nearness. ${ }^{24}$

Dalam sejarah perkembangannya, bongkar pasang konsep pengembangan wilayah di Indonesia terdapat beberapa landasan teori yang turut mewarnai keberadaannya selain dari Teori Hurd yang telah di uraikan di atas. Pertama adalah Walter Isard sebagai pelopor ilmu wilayah yang mengkaji terjadinya hubungan sebab dan akibat dari faktor-faktor utama pembentuk ruang wilayah, yakni faktor fisik, sosial ekonomi dan budaya. Kedua adalah Hirschmann (era 1980an) yang memunculkan teori polarization effect dan trickling down effect dengan argumentasi bahwa perkembangan suatu wilayah tidak terjadi secara bersamaan (unbalanced development). Ketiga adalah Myrdal (era 1950an) dengan teori yang menjelaskan hubungan antara wilayah maju dan wilayah belakangannya dengan menggunakan istilah backwash effect dan spreadwash effect. Keempat adalah Friedmann (era 1960an) yang lebih menekankan pada pembentukan hirarki guna mempermudah pengembangan sistem pembangunan yang kemudian dikenal dengan teori pusat pertumbuhan. Kelima adalah Douglass (era 1970an) yang memperkenalkan lahirnya model keterkaitan desa-kota (ruralurban linkages) dalam pengembangan wilayah. ${ }^{25}$

Teori yang tidak hanya berkaitan dengan tata ruang namun juga berkaitan dengan bidang ilmu hukum karena penelitian ini merupakan penelitian sosiolegal. Teori yang dipilih yaitu yang berkaitan dengan kepatuhan hukum yaitu teori

\footnotetext{
${ }^{24}$ Id, hlm.64.

${ }^{25}$ Hariyanto dan Tukidi, Konsep Pengembangan Wilayah dan Penataan Ruang Indonesia Di Era Otonomi Daerah, Jurnal Geografi, FIS UNNES, Vol 4 No.1 Januari 2007, hlm.1.
} 
kepatuhan (compliance theory) dari Tyler. Teori kepatuhan telah diteliti pada ilmu-limu sosial khususnya di bidang psikologis dan sosiologi yang lebih menekankan pada pentingnya proses sosialisasi dalam mempengaruhi perilaku kepatuhan seorang individu.

Menurut Tyler sebagaimana dikutip oleh Susilowati terdapat dua perspektif dasar dalam literatur sosiologi mengenai kepatuhan pada hukum, yang disebut instrumental dan normatif. ${ }^{26}$ Perspektif instrumental mengasumsikan individu secara utuh didorong oleh kepentingan pribadi dan tanggapan terhadap perubahan-perubahan dalam tangible, insentif, dan penalti yang berhubungan dengan perilaku. Perspektif normatif berhubungan dengan apa yang orang anggap sebagai moral dan berlawanan dengan kepentingan pribadi mereka. ${ }^{27}$

Seorang individu cenderung mematuhi hukum yang mereka anggap sesuai dan konsisten dengan norma-norma internal mereka. Komitmen normatif melalui moralitas personal (normative commitment through morality) berarti mematuhi hukum karena hukum tersebut dianggap sebagai keharusan, sedangkan komitmen normatif melalui legitimasi (normative commitment through legitimacy) berarti mematuhi peraturan karena otoritas penyusun hukum tersebut memiliki hak untuk mendikte perilaku. ${ }^{28}$

Pemahaman mengenai gagasan pembangunan berkelanjutan yang berwawasan lingkungan (sustainable development) penting bagi masyarakat, pemerintah dan juga pengembang yang akan menjalankan bisnis kondominium, karena ketidakpahaman pada gagasan ini akan mengakibatkan penyimpangan tata ruang bahkan pemanfaatan ruang yang mengeksploitasi lingkungan dengan tidak bertanggungjawab.

\footnotetext{
${ }^{26}$ Rahmat Saleh, Supra no 10.

27 Id.

${ }^{28}$ Id, Rahmat Saleh, Supranote 10, hlm.2-3

Berkaitan dengan hal tersebut lebih lanjut Tom R. Tyler juga berpendapat bahwa pengaruh moral jauh lebih penting dari perilaku, secara sukarela bertindak melawan kepentingan pribadi adalah kunci nilai sosial pengaruh normatif. Dengan asumsi seperti ini, diharapkan pemimpin dapat memperoleh kepatuhan sukarela dari tindakan masyarakat, jika tindakan tersebut sesuai dengan pandangan masyarakat tentang benar dan salah, meskipun tidak bermanfaat secara pribadi. Tom R. Tyler, Why People Obey the Law, Yale University Press, New Haven and London, 1990, Pg.24. http://www.psych.nyu.edu/tyler/lab/Chapters_1-4.pdf terakhir diunduh pada tanggal 30 Agustus 2017.
} 
Kesesuaian penggunaan lahan bukan hanya untuk kepentingan pembuat regulasi namun juga bermanfaat bagi kelangsungan hidup manusia di masa depan. Jangan sampai daya tampung bumi tidak sanggup lagi untuk menampung makhluk hidup karena memang penggunaannya tidak sesuai dengan keperuntukannya. Apabila dianalisa lebih jauh peraturan perundangan tentang lingkungan hidup di Indonesia telah sesuai dengan ruh, jiwa atau semangat dari gagasan pembangunan berkelanjutan (sustainable development), bahkan istilah "Pembangunan Berkelanjutan" secara resmi dipergunakan dalam Tap MPR No. IV/MPR/1999 tentang GBHN, sedangkan istilah Pembangunan berwawasan lingkungan hidup digunakan dalam Undang-Undang Nomor 23 Tahun 1997 tentang Pengelolaan Lingkungan Hidup. ${ }^{29}$

Menurut World Commission on Environment and Development (1987) Our Common Future pembangunan berkelanjutan yaitu pembangunan yang memenuhi kebutuhan masa kini, tanpa mengorbankan kemampuan generasi masa depan untuk memenuhi kebutuhan mereka. ${ }^{30}$ World submit on Sustainable Development (WSSD) memuat prinsip-prinsip pembangunan berkelanjutan sebagai pendekatan baru berdasarkan pertimbangan keterkaitan dan kesalingtergantungan pembangunan ekonomi, pembangunan sosial dan pembangunan lingkungan. ${ }^{31}$

Terdapat hubungan yang erat antara kebijakan dan kesejahteraan di mana kebijakan yang dibuat harus memuat nilai-nilai yang tujuan akhirnya mensejahterakan masyarakat, dalam hal ini bukan pada segmen masyarakat tertentu namun kesejahteraan seluas-luasnya.32 Hal tentang kesejahteraan

\footnotetext{
${ }^{29}$ Abdurrahman, Pembangunan Berkelanjutan Dalam Pengelolaan Sumber Daya Alam Indonesia, makalah disampaikan pada: Seminar Pembangunan Hukum Nasional VII Tema Penegakan Hukum Dalam Era Pembangunan Berkelanjutan, diselenggarakan oleh Badan Pembinaan Hukum Nasional, Departemen Kehakiman dan Hak Asasi Manusia RI, Denpasar, 14-18 Juli 2003, hlm.4

${ }^{30}$ Sebagaimana dikutip oleh Jonathan M. Harris, Basic Principles of Sustainable Development, Global Development and Environment Institute working paper 00-04, Tufts University Medford MA 02155, USA, June 2000, pg.5.

${ }^{31}$ Daud Silalahi, Pembangunan Berkelanjutan Dalam Rangka Pengelolaan (Termasuk Perlindungan) Sumber Daya Alam Yang Berbasis Pembangunan Sosisal dan Ekonomi, makalah disampaikan pada: Seminar Pembangunan Hukum Nasional VII Tema Penegakan Hukum Dalam Era Pembangunan Berkelanjutan, diselenggarakan oleh Badan Pembinaan Hukum Nasional, Departemen Kehakiman dan Hak Asasi Manusia RI, Denpasar, 14-18 Juli 2003, hlm. 2.

32 UU Penataan Ruang, Supranote 5, Pasal 7 ayat (1), yang berbunyi: "Negara menyelenggarakan penataan ruang untuk sebesar-besarnya kemakmuran rakyat"
} 
masyarakat tersebut telah terakomodasi dalam Pasal 7 UU Penataan Ruang, yang pada intinya:

1. Memberikan kemakmuran

Peraturan memberikan makna kemakmuran dimaksudkan bahwa penataan ruang mampu mewujudkan kemakmuran ruang yang digunakan oleh masyarakat, mampu memberikan rasa aman, nyaman, sehat dan tidak ada ancaman bahaya. Di sisi lain dalam peraturan ukuran kesejahteraan yang didefinisikan sangat sederhana.

2. Memperhatikan hak-hak setiap orang

Misalnya dalam hal terjadi jual-beli tanah untuk kondominium diharapkan pemerintah dapat memperhatikan dengan seksama, jangan sampai masyarakat yang minim informasi menjadi pihak yang dirugikan oleh pengembang dengan membeli tanah dengan harga dibawah nilai pasar. Dalam hal ini Pemerintah merupakan mediator bagi masyarakat dan pengusaha, dimana negara hadir dalam bentuk pertanggung jawaban pemerintah.

3. Memberikan nilai tambah (value added), menghindarkan penataan ruang justru merugikan masyarakat, tidak memberikan nilai tambah.

4. Adanya aksestabilitas masyarakat

Apabila semua faktor di atas dilaksanakan sesuai dengan peraturan yang berlaku maka akan menciptakan kesejahteraan masyarakat dalam penataan ruang.

Rencana Tata Ruang Wilayah Kota Bandung yang selanjutnya disebut RTRWK adalah arahan kebijakan dan strategi pemanfaatan ruang wilayah. ${ }^{33}$ Pengaturan RTRWK ini penting untuk diatur karena keberadaan ruang yang terbatas dan pemahaman masyarakat yang berkembang terhadap pentingnya penataan ruang, memerlukan penyelenggaraan penataan ruang yang transparan, efektif dan partisipatif, agar terwujud ruang yang aman, nyaman, produktif dan

\footnotetext{
${ }^{33}$ Peraturan Daerah Kota Bandung Nomor: 18 Tahun 2011 tentang Rencana Tata Ruang Wilayah Kota Bandung Tahun 2011-2031, Lembaran Daerah Kota Bandung Tahun 2011 Nomor 18, Pasal 1 angka 19
} 
berkelanjutan. ${ }^{34}$ Berdasarkan pengaturan ini menjadikan zonasi penataan ruang sejalan dengan pembangunan berkelanjutan yang berwawasan lingkungan, karena pada dasarnya RTRWK disusun dengan terlebih dahulu diadakan kajian keilmuan yang komprehensif.

Sanksi bagi penyimpangan ketentuan dalam RTRWK diatur dalam UU Penataan Ruang. Persoalan utama dilanggarnya tata ruang di Indonesia adalah karena penegakan hukumnya yang lemah. ${ }^{35}$ UU Penataan Ruang mengatur tiga sanksi yaitu sanksi administratif (Pasal 62-64), sanksi perdata (Pasal 66,67 dan 75), dan sanksi pidana (Pasal 69-74). ${ }^{36}$ Dalam Pasal 61 dan 62 tentang sanksi administratif, dirumuskan sebagai berikut:

\section{Pasal 61}

Dalam pemanfaatan ruang, setiap orang wajib:

a. Menaati rencana tata ruang yang telah ditetapkan;

b. Memanfaatkan ruang sesuai dengan izin pemanfaatan ruang dari pejabat yang berwenang;

c. Mematuhi ketentuan yang diterapkan dalam persyaratan izin pemanfaatan ruang; dan

d. Memberikan akses terhadap kawasan yang oleh ketentuan peraturan perundang-undangan dinyatakan sebagai milik umum.

\section{Pasal 62}

Setiap orang yang melanggar ketentuan sebagaimana dimaksud dalam Pasal 61, dikenakan sanksi administratif

Sanksi Administratif dapat berupa: (a) peringatan tertulis; (b) penghentian sementara kegiatan; (c) penghentian sementara pelayanan umum; (d) penutupan lokasi; (e) pencabutan izin; (f) pembatalan izin; (g) pembongkaran bangunan; (h) pemulihan fungsi ruang; dan atau (i) denda administratif. ${ }^{37}$

\footnotetext{
${ }^{34}$ Dalam konsideran Perda RTRWK, Supranote 23.

${ }^{35}$ I Wayan Parsa, Laporan Akhir Tim Pengkajian Hukum Tentang Penegakan Hukum Penataan Ruang Dalam Kerangka Otonomi Daerah, Badan Pembinaan Hukum Nasional Kementerian Hukum dan Hak Asasi Manusia R.I, Jakarta, 2014, hlm.7 , http://www.bphn.go.id/data/documents/laporan_lengkap.pdf terakhir diunduh pada tanggal 17 Oktober 2017.

${ }^{37}$ UU Penataan Ruang, Supra no 5, Pasal 63.
} 
Apabila sanksi administratif tidak cukup memberikan efek jera maka pelaku usaha dapat dikenai sanksi pidana apabila kesalahan memenuhi unsur Pasal 69 UU Penataan ruang tentang Ketentuan sanksi Pidana, yaitu: "(1) Setiap orang yang tidak menaati rencana tata ruang yang telah ditetapkan sebagaimana dimaksud dalam Pasal 61 huruf $\mathrm{a}^{38}$ yang mengakibatkan perubahan fungsi ruang, dipidana dengan pidana penjara paling lama 3 (tiga) tahun dan denda paling banyak Rp500.000.000.000,-(lima ratus juta rupiah).”

\section{Temuan Dan Analisa}

\section{Kasus Kondominium La Grande Merdeka Tamansari}

Telah dibahas pada bagian pendahuluan latar belakang bahwa awal mula dilakukan penelitian pada penyimpangan tata ruang di kota bandung khususnya pada pembangunan kondominium yaitu karena terdapat data awal bahwa pembangunan kondominium yang kurang lebih sejarak 4 meter dari pemukiman. Dalam hal ini warga menyangsikan surat izin gangguan (Hinder Ordonantie atau H.O) ${ }^{39}$ yang dikeluarkan oleh Pemerintah kepada Pelaku Usaha. Berkaitan dengan pembangunan kondominium La Grande Merdeka Tamansari, selanjutnya ditelusuri lebih lanjut penggunaan lahan di kota Bandung dalam Rencana Tata Ruang Wilayah kota Bandung 2011-2031 khusus bagi pembangunan kondominium.

\footnotetext{
38 Id, Supra no 5, Pasal 61 huruf a adalah sebagai berikut:

"Dalam pemanfaatan ruang, setiap orang wajib:

a. Menaati rencana tata ruang yang telah ditetapkan;........"

39 Tujuan utama dari dokumen ini adalah untuk memperkuat fungsi izin gangguan sebagai alat untuk mengendalikan pengaruh negatif dari luar yang mungkin ditimbulkan oleh kegiatankegiatan sosial ekonomi tertentu, dan untuk melakukan penyederhanaan sehingga ijin gangguan tidak membenani iklim usaha.

Tinjauan sejarah tentang Undang-Undang Gangguan Staatsblad (Lembaran Negara) tahun 1926, nomor 226, Staatsblad tahun 1940, nomor 450, dan Peraturan Menteri Dalam Negeri No.7 Tahun 1993 tentang Ijin Mendirikan Bangunan dan Ijin Gangguan, lebih lanjut dalam Donald L. Elliott, Sistem Perijinan Gangguan Sebuah Laporan Tentang Pengendalian Kekacauan, didukung oleh United States Agency for International Development (USAID), Juli, 2008, Ulasan Tentang Dokumen Latar Belakang Gangguan, hlm.3.

Menurut ordonantie ini akan dikenakan larangan kepada siapapun untuk mendirikan tempat usaha yang dapat menimbulkan bahaya, kerugian, dan gangguan, kecuali apabila mendapatkan izin dari yang terkena gangguan. Gangguan yang dimaksud meliputi gangguan getaran, kebisingan, cahaya, dan bau.
} 


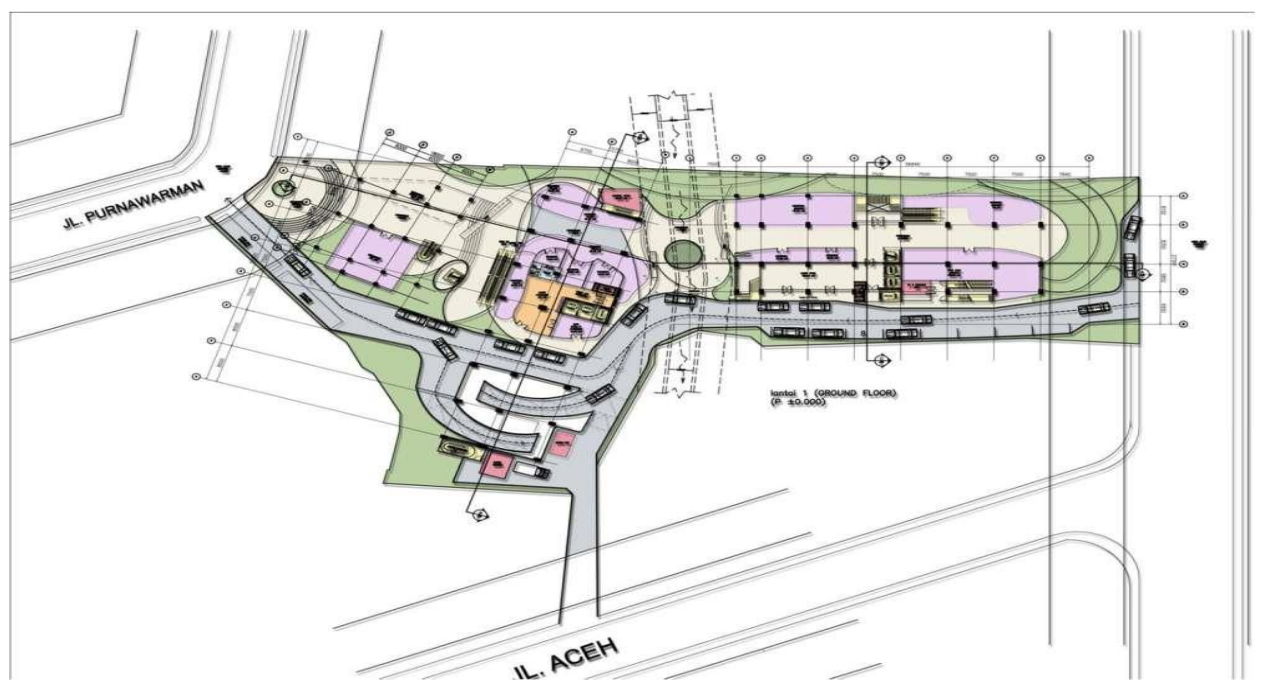

Gambar 1

Site Plan pembangunan kondominium La Grande Merdeka Taman Sari

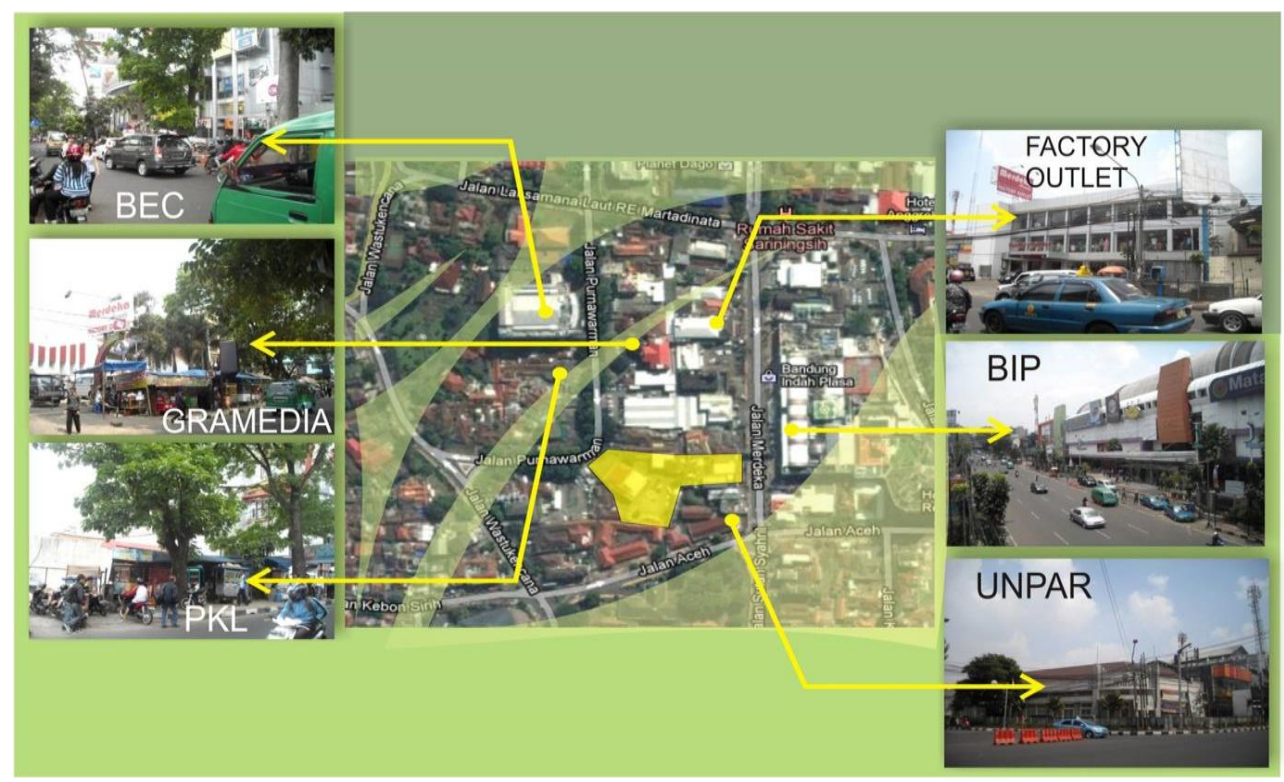

\section{Gambar 2}

Pada gambar 1.2 ini diperlihatkan bahwa pembangunan kondominium La Grande Merdeka Tamansari dibangun antara pusat perbelanjaan dan memang terdapat RTRW kota Bandung bahwa wilayah Jalan Merdeka apabila diadakan pembangunan, maka pembangunan itu khusus untuk pusat perbelanjaan. ${ }^{40}$

40 Site Plan Kondominium La Grande Merdeka, Gambar terakhir diunggah pada tanggal 23 Agustus 2017

https://www.google.co.id/search?q=site+plan+la+grande+merdeka\&source=lnms\&tbm=isch\&sa =X\&ved=0ahUKEwilsfqdqezVAhURT48KHXs3DosQ_AUICigB 
Berdasarkan 2 (dua) gambar di atas diperlihatkan bahwa terjadi penyimpangan penggunaan tata ruang dengan adanya pembangunan kondominium La Grande Merdeka Tamansari, karena dalam RTRW tahun 20112031 kota Bandung diatur bahwa peruntukan Jalan merdeka untuk pusat perbelanjaan dengan maksud kegiatan ekonomi masyarakat terpusat tidak tercampur antara pemukiman dan pusat perbelanjaan. Berdasarkan hal tersebut maka dapat diindikasikan adanya ketidak konsistenan antara produk kebijakan dengan pembuat kebijakan itu sendiri, karena pada dasarnya telah dibangun kondominium berdasarkan izin dari pemegang kewenangan. Disini dibutuhkan adanya pemahaman pada peraturan bagi pemerintah khususnya Pemerintah Daerah akan kepatuhan terhadap RTRWK. Dibutuhkan pemerintah yang tegas pada penerapan RTRWK karena pada saat pembuatan RTRWK melibatkan pihakpihak yang memiliki kompetensi dalam perencanaan tata ruang sehingga telah diperhitungkan secara seksama demi kebaikan dan kepentingan bersama saat ini dan masa depan.

\section{Kasus Kondominium Pullman Bandung City Center}

Contoh berikutnya adalah kondominium bernama Pullman Bandung City Center yang dianggap pembangunannya menyalahi aturan pembangunan. Pengembang pembangunan Pullman Bandung City Center merupakan pengembang proyek hotel dan kondominium yang terkemuka. Walaupun pengembang pembangunan kondominium Pullman merupakan pengembang yang terkemuka namun tidak secara otomatis bahwa pengembang tersebut paham dan taat pada hukum yang berlaku.

Pembangunan kondominium Pullman menimbulkan beberapa kontroversi karena pembangunan kondominium dibangun tepat berhadapan dengan Gedung Sate yang mana merupakan gedung Pemerintahan Provinsi Jawa Barat. ${ }^{41}$ Setelah

\footnotetext{
${ }^{41}$ Gedung Sate, dengan ciri khasnya berupa ornamen tusuk sate pada menara sentralnya, telah lama menjadi penanda atau markah tanahKota Bandung yang tidak saja dikenal masyarakat di Jawa Barat, namun juga seluruh Indonesia bahkan model bangunan itu dijadikan pertanda bagi beberapa bangunan dan tanda-tanda kota di Jawa Barat. Misalnya bentuk gedung bagian
} 
ditelusuri bahwa pihak pengembang mengacu pada Izin Mendirikan Bangunan (IMB) proyek yang merupakan produk hukum tahun 1997. Dalam ketentuan IMB Tahun 1997 diatur bahwa diperbolehkan terdapat bangunan sampai 14 lantai, akan tetapi untuk saat ini berubah sudah tidak sesuai. ${ }^{42}$

Tidak hanya permasalahan ketinggian dari Pullman yang melebihi ketinggian Gedung Sate yang menjadi sorotan, namun juga terdapat penggunaan trotoar yang dipakai sebagai bagian dari sarana pembangunan kondominium. Hal ini bertentangan dengan pemanfaatan trotoar sebagai sarana fasilitas umum. Pengembang Pullman dibebaskan untuk memakainya sebagai sarana pembangunan kondominium, dimana hal ini bertentangan dengan peruntukkan penggunaan trotoar sebagaimana mestinya.

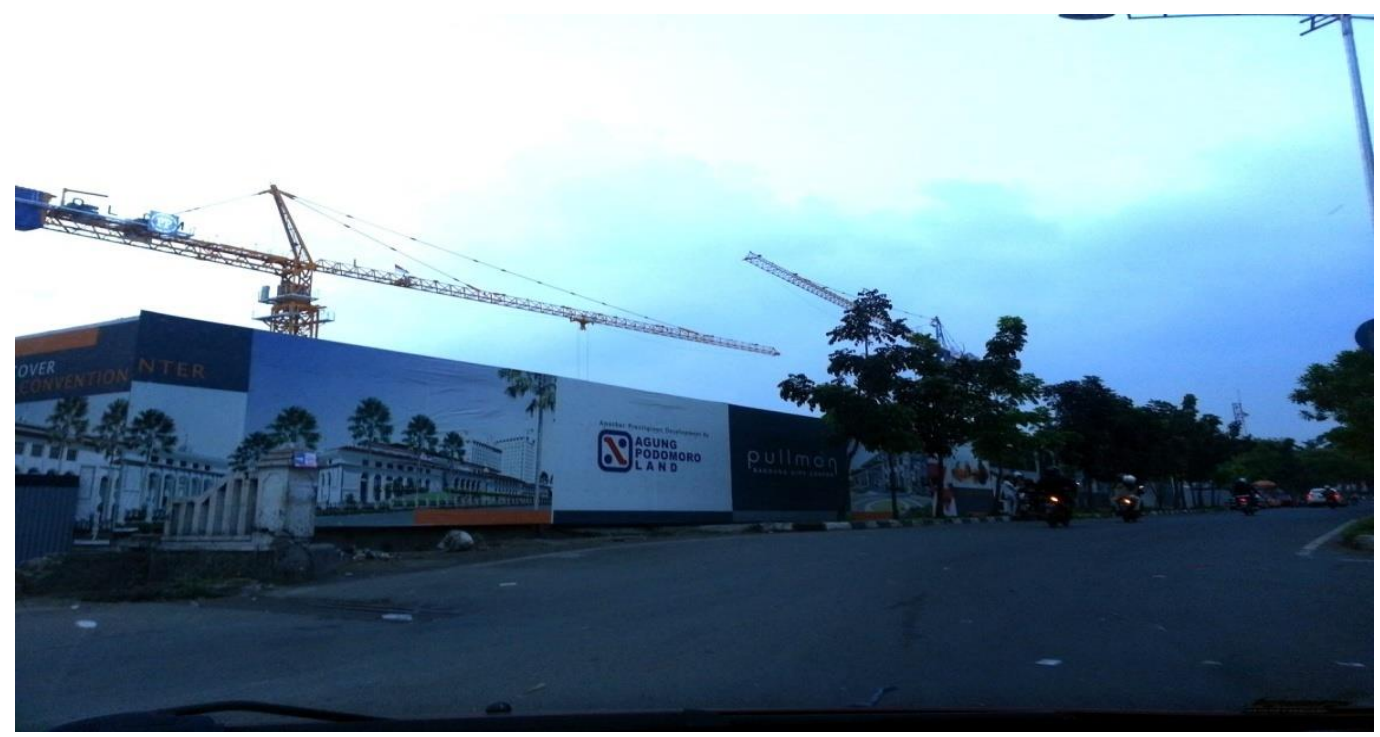

Gambar 3

Pengembang proyek pembangunan Pullman menutup trotoar dengan pagar pembatas pembangunan.

depan Stasiun Kereta Api Tasikmalaya. Mulai dibangun tahun 1920, gedung berwarna putih ini masih berdiri kokoh namun anggun dan kini berfungsi sebagai gedung pusat pemerintahan Jawa Barat. http://id.wikipedia.org/wiki/Gedung_Sate terakhir diakses pada tanggal 26 Agustus 2017.

42 Tempo, Izin Hotel Pullman Bandung Harus Ditinjau Ulang, https://nasional.tempo.co/read/562037/izin-hotel-pullman-bandung-harus-ditinjau-ulang terakhir diakses tanggal 17 Oktober 2017 


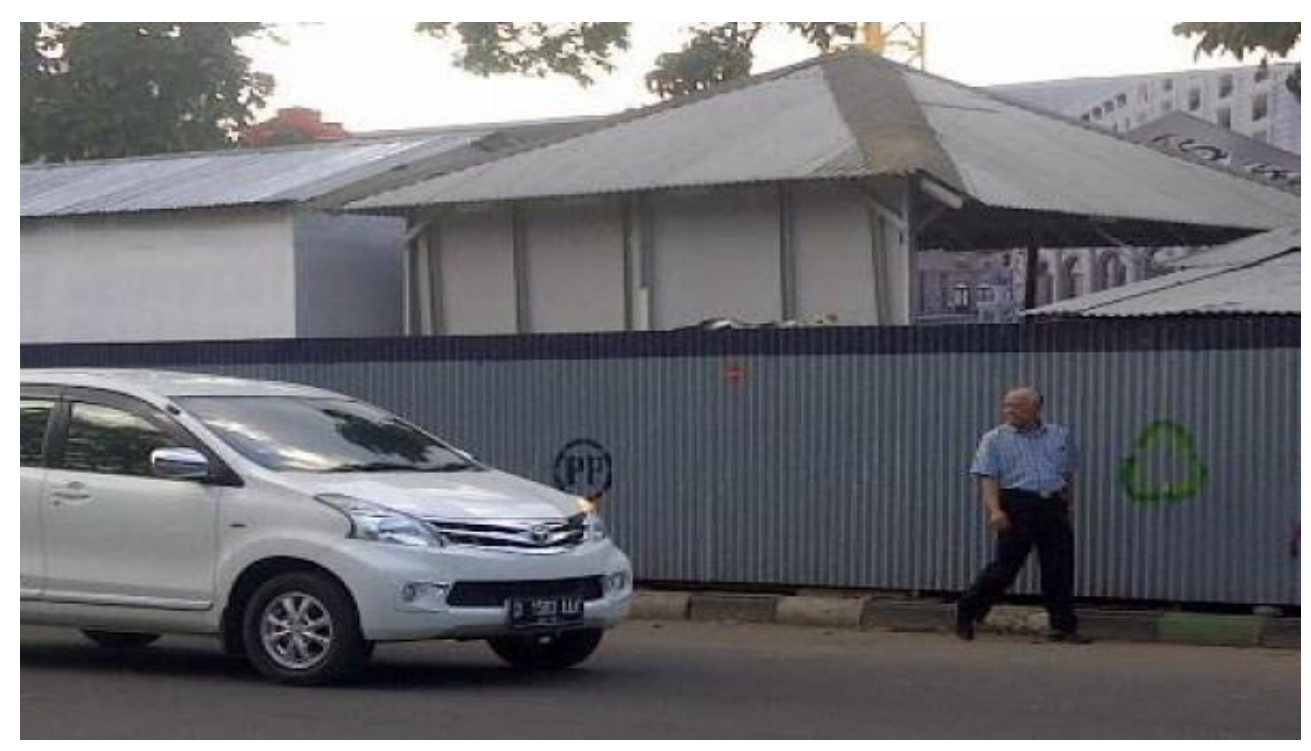

\section{Gambar 4}

Menggambarkan seorang paruh baya sebagai pejalan kaki yang sedang memperhatikan kendaraan dibelakangnya sebagai bentuk kewaspadaan karena ia terpaksa berjalan kaki di bahu jalan akibat trotoar yang ditutup oleh pagar pembatas bangunan proyek pembangunan kondominium Pullman Bandung City Center.

\section{Kasus Kondominium Grand Dago}

Penyimpangan juga diduga dilakukan oleh kondominium bernama Grand dago yang terletak di Jalan Bayangbang RT 005/008 Kelurahan Sekeloa Kecamatan Coblong dan kawasan ini termasuk ke dalam Kawasan Bandung Utara $(\mathrm{KBU})^{43}$.

KBU memiliki fungsi dan peranan penting dalam menjamin keberlanjutan kehidupan dan keseimbangan lingkungan hidup di Cekungan Bandung, telah ditetapkan menjadi Kawasan Strategis Provinsi. ${ }^{44}$ Pemanfaatan ruang di KBU yang

\footnotetext{
${ }^{43}$ Kawasan Bandung Utara yang selanjutnya disebut KBU adalah kawasan yang meliputi sebagian wilayah Kabupaten Bandung, Kota Bandung, Kota Cimahi dan Kabupaten Bandung Barat dengan batas di sebelah utara dan timur dibatasi oleh punggung topografi yang menghubungkan puncak Gunung Burangrang, Masigit, Gedongan, Sunda, Tangkubanparahu dan Manglayang, sedangkan di sebelah barat dan selatan dibatasi oleh garis (kontur) $750 \mathrm{~m}$ di atas permukaan laut (dpl)

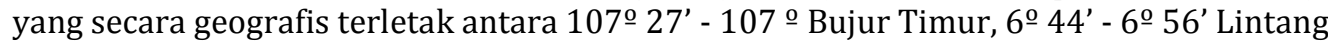
Selatan. Pasal 1 angka 25 Peraturan Daerah Kota Bandung Nomor 18 tahun 2011 tentang Rencana Tata Ruang Wilayah Kota Bandung tahun 2011-2031.

${ }^{44}$ Berdasarkan Peraturan Daerah Provinsi Jawa Barat Nomor 22 Tahun 2010 tentang Rencana Tata Ruang Wilayah Provinsi Jawa Barat Tahun 2009-2029.
} 
tidak terkendali akan mengancam keberlangsungan fungsi konservasi kawasan sebagai tangkapan air dan menimbulkan berbagai bencana. ${ }^{45}$

Berbagai dampak negatif lingkungan mulai dirasakan, seperti longsor, meningkatnya limpasan air, berkurangnya daerah resapan, hilangnya beberapa mata air, berkurangnya debit mata air, hingga berkurangnya kesejukan udara. Dampak lain adalah terjadinya gangguan pada cadangan dan konservasi air, karena KBU merupakan sub DAS Cikapundung, Cimahi, Citarik Hulu, Cigugur, Cibeureum, Citepus dan beberapa anak sungai lainnya yang bermuara di Sungai Citarum. Oleh karena itu, perlu upaya pengendalian yang ketat dan tepat terhadap pembangunan di KBU dalam rangka mengembalikan kondisi fungsi hidroorologis terutama pada lahan dengan kondisi sangat kritis. ${ }^{46}$

Menurut Direktorat Geologi dan Tata Lingkungan, sedikitnya 60\% dari sekitar 108 juta $\mathrm{M}^{3}$ air tanah dari dataran tinggi sekitar Bandung yang masuk ke cekungan Bandung berasal dari Kawasan Bandung Utara, dengan demikian kawasan ini berfungsi sebagai kawasan resapan air yang memepunyai peran sangat penting dalam penyediaan air tanah baik untuk wilayah Bandung Utara tersebut maupun untuk daerah cekungan Bandung. ${ }^{47}$

Berdasarkan pemaparan mengenai KBU di atas nampak bahwa pembangunan kondominium Grand Dago telah menyalahi aturan tata ruang karena dibangun di Kawasan Bandung Utara. Berikut disajikan dalam bentuk tabel data pembangunan kondominium, letak, serta peruntukannya sesuai dengan RTRW Kota Bandung tahun 2011-2031.

\begin{tabular}{|c|c|c|c|c|}
\hline No & $\begin{array}{c}\text { Nama } \\
\text { Kondominium }\end{array}$ & Alamat & $\begin{array}{l}\text { Seharusnya peruntukan atau } \\
\text { permasalahan yang terjadi }\end{array}$ & $\begin{array}{c}\text { Harga } \\
\text { per-unit }\end{array}$ \\
\hline 1 & $\begin{array}{l}\text { La Grande Merdeka } \\
\text { Tamansari }\end{array}$ & $\begin{array}{l}\text { Jl Merdeka No. 25- } \\
\text { 29, Bandung }\end{array}$ & Pusat perbelanjaan (tidak sesuai) & Rp.1.1M \\
\hline 2 & $\begin{array}{l}\text { Pullman Bandung } \\
\text { City Center }\end{array}$ & $\begin{array}{l}\text { Jl. Diponegoro dan Jl. } \\
\text { Surapati }\end{array}$ & $\begin{array}{l}\text { Pembangunannya menyalahi } \\
\text { aturan dalam IMB kota bandung. } \\
\text { (tidak sesuai) }\end{array}$ & - \\
\hline
\end{tabular}

\footnotetext{
45 Peraturan Daerah Provinsi Jawa Barat Nomor 2 Tahun 2016 tentang Pedoman Pengendalian Kawasan Bandung Utara sebagai Kawasan Strategis Provinsi Jawa Barat, Lembaran Daerah Provinsi Jawa Barat Tahun 2016 Nomor 2 Seri E, Konsideran Huruf a dan b.

46 Id, dalam Penjelasan Ketentuan Umum.

${ }^{47}$ Ketut Wikantika, Ashwin Ismail dan Akhmad Riqqi, Bandung Utara Nasibmu Kini. Departemen Teknik Geodesi ITB, www.Pikiranrakyat.com edisi Kamis 7 April 2005. Terakhir diakses pada tanggal 26 Agustus 2017.
} 


\begin{tabular}{|c|c|c|c|c|}
\hline 3 & The Pavilijoen & Jl. LLRE Martadinata & $\begin{array}{l}\text { Mempertahankan perumahan } \\
\text { terencana yang menjadi ciri khas } \\
\text { kota dalam kerangka } \\
\text { perlindungan cagar budaya } \\
\text { (Tidak untuk pembangunan } \\
\text { secara vertikal). }\end{array}$ & $\begin{array}{l}\text { Rp.600jut } \\
\mathrm{a}\end{array}$ \\
\hline 4 & Margahayuland & $\begin{array}{l}\text { Jl. Soekarno Hatta No } \\
693\end{array}$ & $\begin{array}{l}\text { Kawasan pemukiman dan pusat } \\
\text { pengembangan perdagangan } \\
\text { grosir (sesuai) }\end{array}$ & $\begin{array}{l}\text { Rp.500- } \\
750 \text { juta }\end{array}$ \\
\hline 5 & Dago Suite & Jl. Dago Timur & $\begin{array}{l}\text { Mempertahankan perumahan } \\
\text { terencana yang menjadi ciri khas } \\
\text { kota dalam kerangka } \\
\text { perlindungan cagar budaya } \\
\text { (tidak sesuai) }\end{array}$ & Rp. 1,3M \\
\hline 6 & Newton Residence & $\begin{array}{l}\text { Jl. Terusan Buah } \\
\text { Batu }\end{array}$ & Kawasan pemukiman (sesuai) & Rp.1,2M \\
\hline 7 & Galeri Ciumbuleuit & $\begin{array}{l}\text { Jl. Ciumbuleuit No } 42 \\
\text { A, Hegarmanah, } \\
\text { Cidadap, Kota } \\
\text { Bandung }\end{array}$ & Daerah resapan air (tidak sesuai) & Rp.1,4M \\
\hline 8 & Royal Apartments & Jl. Cipaku & Kawasan pemukiman (sesuai) & - \\
\hline 9 & Setra Manunggal & Jl. Manunggal no.7 & Kawasan pemukiman (sesuai) & - \\
\hline 10 & Sriti apartment & $\begin{array}{l}\text { Jl. Hegarmanah } \\
\text { No.11 }\end{array}$ & Kawasan pemukiman (sesuai) & - \\
\hline 11 & Landmark Residence & Jl. Bima No.81 & $\begin{array}{l}\text { Mempertahankan perumahan } \\
\text { terencana yang menjadi ciri khas } \\
\text { kota dalam kerangka } \\
\text { perlindungan cagar budaya. } \\
\text { (tidak untuk pembangunan } \\
\text { secara vertikal). }\end{array}$ & Rp.1M \\
\hline 12 & Sudirman Suite & Jl. Sudirman & Kawasan pemukiman (sesuai) & $\begin{array}{l}\text { Rp.1,075 } \\
\text { M }\end{array}$ \\
\hline 13 & Grand Asia-Afrika & Jl. Sunda & Kawasan pemukiman (sesuai) & $\begin{array}{l}\text { Rp.400- } \\
\text { 500juta }\end{array}$ \\
\hline 14 & Grand Dago & $\begin{array}{l}\text { Jl. Bangbayang } \\
\text { RT05/08 Kel.sekeloa } \\
\text { Kec.Coblong }\end{array}$ & $\begin{array}{l}\text { Termasuk dalam KBU (Kawasan } \\
\text { Bandung Utara)KBU termasuk } \\
\text { kawasan lindung untuk } \\
\text { mempertahankan, memelihara } \\
\text { dan meningkatkan kualitas RTH } \\
\text { (Ruang Terbuka Hijau) terhadap } \\
\text { kawasan bahwahannya. }\end{array}$ & $\begin{array}{l}\text { Rp.866 } \\
\text { juta }\end{array}$ \\
\hline 15 & Apartemen Gateway & $\begin{array}{l}\text { Jl. Jend. A. Yani } \\
\text { No.669, Padasuka, } \\
\text { Cibeunying Kidul, } \\
\text { Kota Bandung, Jawa } \\
\text { Barat } 40125\end{array}$ & $\begin{array}{l}\text { Pengembangan kawasan } \\
\text { perumahan (sesuai) }\end{array}$ & $\begin{array}{l}\text { Rp.400jut } \\
\text { a }\end{array}$ \\
\hline 16 & $\begin{array}{l}\text { Tamansari Kencana } \\
\text { Wika Realty }\end{array}$ & $\begin{array}{l}\text { Jl. Sulaksana, } \\
\text { Terusan jalan } \\
\text { Jakarta, Antapani, } \\
\text { Bandung }\end{array}$ & $\begin{array}{l}\text { Pengembangan kawasan } \\
\text { perumahan (sesuai) }\end{array}$ & Rp380Juta \\
\hline 17 & The Maj Condotel & Jl. Ir. Haji Juanda, Gg. & Kawasan pelestarian alam adalah & Rp.1.167 \\
\hline
\end{tabular}




\begin{tabular}{|c|c|c|c|c|}
\hline & $\begin{array}{l}\text { and Apartment Dago } \\
\text { Bandung }\end{array}$ & $\begin{array}{l}\text { A. Wijaya No.471, } \\
\text { Coblong, Dago, } \\
\text { Bandung. }\end{array}$ & $\begin{array}{l}\text { Kawasan Taman Hutan Raya } \\
\text { Juanda di Kelurahan Dago, } \\
\text { Kecamatan Coblong } \\
\text { dengan luasan lebih kurang 2,96 } \\
\text { (dua koma sembilan puluh } \\
\text { enam) hektar. (Tidak sesuai) }\end{array}$ & $\mathrm{M}$ \\
\hline 18 & $\begin{array}{l}\text { Buah Batu Park } \\
\text { Apartment }\end{array}$ & $\begin{array}{l}\text { Jl. Adhyaksa Raya } \\
\text { No.1, Mengger, } \\
\text { Bandung Kidul, Kota } \\
\text { Bandung }\end{array}$ & $\begin{array}{l}\text { Pengembangan kawasan } \\
\text { perumahan (sesuai) }\end{array}$ & $\begin{array}{l}\text { Rp. } 400 \\
\text { juta }\end{array}$ \\
\hline 19 & $\begin{array}{l}\text { Emerald Tower } \\
\text { Bandung }\end{array}$ & $\begin{array}{l}\text { Jl. Sanggar Kencana } \\
\text { Bandung XXVII, } \\
\text { Jatisari, Buahbatu, } \\
\text { Bandung }\end{array}$ & $\begin{array}{l}\text { Pengembangan kawasan } \\
\text { perumahan (sesuai) }\end{array}$ & $\begin{array}{l}\text { Mulai dari } \\
\text { Rp.250 } \\
\text { juta }\end{array}$ \\
\hline 20 & $\begin{array}{l}\text { Apartment } \\
\text { Parahyangan } \\
\text { Residences }\end{array}$ & $\begin{array}{l}\text { Jl. Ciumbuleuit Raya } \\
\text { No. } \\
\text { 125(40141) Bandun } \\
\text { g Utara, Jabar - (50 m } \\
\text { dari Unpar) }\end{array}$ & $\begin{array}{l}\text { Daerah resapan air, kawasan } \\
\text { bandung utara. (tidak sesuai) }\end{array}$ & Rp.1.1M \\
\hline 21 & $\begin{array}{l}\text { The Jardin } \\
\text { Cihampelas }\end{array}$ & $\begin{array}{l}\text { Jl. Cihampelas } \\
\text { Belakang No. } 10\end{array}$ & $\begin{array}{l}\text { Kawasan Strategis Kota Sentra } \\
\text { Jeans Cihampelas yaitu kawasan } \\
\text { strategis } \\
\text { yang ditetapkan berdasarkan } \\
\text { sudut kepentingan ekonomi. }\end{array}$ & $\begin{array}{l}\text { Rp.200- } \\
900 \text { Juta }\end{array}$ \\
\hline 22 & $\begin{array}{l}\text { The Suites Metro } \\
\text { Bandung }\end{array}$ & $\begin{array}{l}\text { Jl. Soekarno Hatta } \\
\text { No. 689. Bandung }\end{array}$ & $\begin{array}{l}\text { Kawasan pemukiman dan pusat } \\
\text { pengembangan perdagangan } \\
\text { grosir (sesuai) }\end{array}$ & $\begin{array}{l}\text { Mulai dari } \\
\text { Rp.399 } \\
\text { Juta }\end{array}$ \\
\hline
\end{tabular}

Salah satu faktor yang paling berpengaruh terhadap penyimpangan tata ruang di kota Bandung terkait dengan pembangunan kondominium itu adalah berkaitan dengan masalah perizinan. Asep Warlan Yusuf mengungkapkan bahwa izin adalah suatu instrumen pemerintah yang bersifat yuridis preventif, yang digunakan sebagai sarana hukum administrasi untuk mengendalikan perilaku masyarakat. ${ }^{48}$ Mencermati uraian di atas, dapat dipahami bahwa izin dalam kontek pengelolaan lingkungan memuat batasan dan berfungsi sebagai ${ }^{49}$ :

a. Alat legitimasi dari suatu larangan untuk diperbolehkannya suatu kegiatan.

b. Instrumen hukum administrasi yang bersifat preventif dalam pengendalian pencemaran lingkungan.

48 Asep Warlan Yusuf, Bahan Kuliah Hukum Perizinan dalam Bisnis, Program Pascasarjana Ilmu Hukum Universitas Katolik Parahyangan, Bandung, 1999.

49 Id, hlm.74. 
c. Berisikan limitasi atau syarat-syarat teknis tentang pertimbangan dikeluarkannya izin untuk beroperasinya suatu kegiatan. ${ }^{50}$

d. Landasan hukum administrasi guna melakukan tindakan represif apabila dalam pelaksanaannya tidak memenuhi limitasi yang tertuang dalam izin khususnya dan peraturan perundang-undangan umumnya.

Penemuan penting dari penelitian ini akan disajikan dalam rangkaian argumentasi agar memudahkan untuk dipahami. Penulis setuju dengan teori yang dikemukakan oleh Tyler terkait dengan teori kepatuhan (compliance theory) yang menyatakan bahwa terdapat dua perspektif dasar mengenai kepatuhan hukum yaitu instrumental dan normatif. Perspektif instrumental mengasumsikan individu secara utuh didorong oleh kepentingan pribadi dan tanggapan-tanggapan terhadap perubahan insentif, dan sanksi yang berhubungan dengan perilaku. Perspektif normatif berhubungan dengan hal yang orang anggap sebagai moral dan berlawanan dengan kepentingan pribadi mereka.

Terbukti dalam beberapa kasus yang telah diungkapkandi atas, beberapa kondominium yang menyimpangi aturan tata ruang dipengaruhi oleh beberapa faktor salah satunya yaitu faktor pemerintah, di mana terjadinya "kelonggaran" dalam menegakan hukum. Terlepas dari adanya kepentingan pribadi dengan menerbitkan izin pembangunan kondominium sehingga terjadi ketidakpatuhan terhadap hukum. Apabila pemerintah melakukan hal yang sebaliknya maka yang terjadi adalah adanya kepatuhan terhadap hukum yang berhubungan dengan apa yang masyarakat anggap sebagai moral.

Pembangunan kondominium memang merupakan ide yang sangat strategis dengan menyediakan tempat tinggal yang dapat menampung banyak orang tetapi dengan memanfaatkan lahan yang cenderung lebih sedikit. Akan tetapi harus pula diperhitungkan mengenai kondisi tanah dan peruntukannya, hingga tanah untuk ruang terbuka hijau digunakan untuk pemukiman atau penyimpangan lainnya.

Faktor-faktor yang menyebabkan terjadinya penyimpangan tata ruang khususnya pada pembangunan kondominium dipengaruhi oleh 3 (tiga) faktor,

50 Juniarso Ridwan dan Achmad Sodik, Supra no 12, hlm.73 
yaitu: (1) Faktor Masyarakat, (2) Faktor Pemerintah, dan (3) Faktor Kekuatan Pasar. Ketiga faktor penyebab ini tidak berdiri sendiri-sendiri namun saling mempengaruhi.

Faktor Pertama yaitu Faktor Masyarakat, adalah salah satu faktor yang mempengaruhi terjadinya penyimpangan penggunaan tata ruang kota yaitu masyarakat yang kurang memahami tentang Rencana Tata Ruang Wilayah Kota Bandung. Hal ini memudahkan bagi pihak pengembang proyek pembangunan kondominium (yang beritikad buruk) untuk meminta salah satu syarat izin gangguan (Hinder Ordoinantie atau H.O) kepada masyarakat sekitar demi memenuhi syarat untuk mendapatkan Izin Mendirikan Bangunan (IMB). Masyarakat yang memahami RTRW di kota Bandung persentasenya lebih kecil dibandingkan dengan masyarakat yang tidak mengetahui. Pada akhirnya pengembang dapat sedikit demi sedikit memenuhi persyaratan dalam membangun kondominium.

Faktor Kedua yang menjadi salah satu faktor yang mendorong terjadinya penyimpangan tata ruang yaitu Faktor Pemerintah. Untuk menegakan konsistensi dalam menjalankan RTRW Kota Bandung 2011-2031 dibutuhkan pemerintah yang secara profesional yang bekerja demi masyarakat bukan untuk kepentingan pribadi. Selain itu dibutuhkan pemerintah yang secara konsisten meneruskan program pemerintah sebelumnya agar rencana program jangka panjang dapat terselesaikan dengan tidak meneruskan kekeliruan yang telah dibuat oleh pemerintah terdahulu.

Faktor Ketiga yang mempengaruhi terjadinya penyimpangan terhadap penggunaan tata ruang Kota Bandung yaitu Faktor Kekuatan Pasar. Faktor ini dianggap sebagai faktor yang memiliki kekuatan paling dominan dalam mendorong terjadinya penyimpangan tata ruang di kota Bandung. Ditinjau dari kondisi kota Bandung saat ini, kota Bandung perkembangannya sangat meningkat khususnya di bidang pertumbuhan ekonomi. Hal ini disebabkan oleh adanya akses cepat jalan tol Cipularang yang menghubungkan kota Bandung dengan kota-kota lain khususnya dengan ibu kota negara, hal ini menyebabkan banyak masyarakat 
yang bukan warga asli Bandung datang ke kota Bandung untuk sekedar berwisata, karena hal ini mendorong pelaku bisnis untuk berinvestasi di kota Bandung.

Meninjau banyaknya peluang bisnis di Kota Bandung, menimbulkan ketertarikan bagi pengembang proyek pembangunan kondominium dengan niat mencari keuntungan dari Kota Bandung untuk menyediakan hunian atau tempat menginap yang bagus, nyaman dan mewah. Mengapa diklasifikasikan kondominium dengan kemewahan karena telah disampaikan sebelumnya pada bagian pembahasan pada kondominium La Grande Merdeka Tamansari yang dijual dengan harga per unit Rp.1.100.000.000 (satu milyar seratus juta rupiah).

Berkaitan dengan pendapatan per kapita penduduk Kota Bandung, menurut RKPD tahun 2014 pendapatan per kapita (atas dasar harga konstan) Kota Bandung berada di atas level nasional, hal ini menunjukan bahwa tingkat kesejahteraan masyarakat Kota Bandung relatif lebih baik jika dibandingkan dengan rata-rata tingkat nasional. Pendapatan per kapita di tahun 2011 sebesar Rp10,160,000 (sepuluh juta seratus enam puluh ribu rupiah) per orang. ${ }^{51}$

Berdasarkan data pendapatan per kapita penduduk kota Bandung bahwa segmen masyarakat yang menjadi konsumen kondominium besar kemungkinan bukan merupakan warga kota Bandung, karena bila berpijak pada data pendapatan per kapita penduduk Kota Bandung dengan pendapatan sejumlah tersebut tidak memungkinkan untuk membeli kondominium yang harganya melebihi pendapatan. Sehingga dapat disimpulkan bahwa salah satu faktor yang menyebabkan terjadinya penyimpangan tata ruang Kota Bandung yaitu adanya kekuatan pasar yang berasal dari luar kota Bandung untuk berinvestasi di Kota Bandung mengingat nilai keuntungan yang akan diperoleh cukup bernilai.

Besar kemungkinan kekuatan pasar tersebut berasal dari penduduk ibu Kota Negara yaitu dari DKI Jakarta karena nilai pendapatan per kapita dari penduduk DKI Jakarta memungkinkan untuk membeli kondominium di Kota Bandung.

\footnotetext{
${ }^{51}$ Revisi Kedua Rencana Kerja Pembangunan Daerah (RKPD) Kota Bandung tahun 2014, hlm.II-15, https://ppid.bandung.go.id/wp-content/uploads/2016/09/RKPD_2014.pdf terakhir diunduh pada tanggal 26 Agustus 2017.
} 


\section{Penutup}

Dari beberapa faktor yang dibahas dalam penelitian tersebut di atas dapat disimpulkan bahwa faktor yang mempengaruhi terjadinya penyimpangan penggunaan tata ruang Kota Bandung tidak hanya di pegaruhi oleh faktor masyarakat dan faktor ketegasan pemerintah namun ada satu lagi faktor yang mendominasi yaitu faktor kekuatan pasar yang seyogianya penting untuk dipertimbangkan oleh pembuat kebijakan agar tidak merusak tatanan yang telah direncanakan.

Untuk meminimalisir kekurangan informasi pengaturan tata ruang salah satu upaya yang dapat dilakukan untuk mencegah terjadinya penyimpangan tata ruang Kota Bandung yaitu dengan melakukan penyuluhan mengenai adanya RTRW Kota Bandung tahun 2011-2031 kepada masyarakat. Secara maksimal memberikan penyuluhan dan sosialisasi peraturan lama maupun peraturan terbaru kepada masyarakat peruntukan wilayah-wilayah di Bandung diperuntukkan untuk apa saja sehingga masyarakat bisa lebih kritis, atau secara minimal masyarakat yang tinggal di wilayah yang mereka duduki mengetahui peruntukkan wilayah mereka menurut RTRW Kota Bandung untuk apa sehingga masyarakat apabila dimintai persetujuan untuk membangun bangunan tidak secara asal memberikan persetujuan.

Dibutuhkan Pemerintah yang konsisten menegakan penataan ruang sebagai salah satu contoh, Walikota Kota Bandung Ridwan Kamil S.T., MUD turut serta membenahi tata ruang kota Bandung memimpin langsung pembongkaran area parkir dari Mall Paris Van Java. Walaupun hal ini bukan terkait dengan pembangunan kondominium namun berikut ini terlihat bahwa seorang pemimpin yang tegas dalam menegakkan tata ruang sesuai dengan RTRW kota Bandung 2011-2031.

Luas lahan parkir dan basement yang dibongkar mencapai $1.200 \mathrm{M}^{2}$, pembongkaran dilakukan oleh tim Dinas Tata Ruang dan Cipta Karya yang di awasi dan dipimpin langsung oleh Walikota Kota Bandung sebagai perwakilan dari Pemerintah Kota Bandung. Menurut Ridwan Kamil Mall PVJ telah melanggar 
peraturan tentang jatah Koefisiensi Dasar Hijau (KDH) ${ }^{52}$ yang sudah sepatutnya dimiliki oleh bangunan besar komersial. Dijelaskan oleh Walikota Bandung bahwa yang dimaksud dengan KDH adalah zona di mana disediakan disekitar bangunan besar komersial sebagai ruang yang dari atas sampai bawah hanya hijau (tumbuhan) dan tanah, bukan di atas pot, di bawah ada basement yang seperti ini bukan KDH dan ini yang terdapat di PVJ. ${ }^{53}$

Berdasarkan hal tersebut maka dapat disimpulkan bahwa salah satu faktor terjadinya penyimpangan tata ruang di kota Bandung adalah pemerintah yang tidak tegas dan dapat dianggap memiliki kepentingan pribadi bukan untuk kepentingan bersama. Terbukti dengan terpilihnya Walikota Bandung yang baru secara tegas memperhatikan ruang terbuka hijau sebagai hak bersama untuk menghirup udara segar yang akan dihasilkan oleh tanaman hijau itu sendiri. Sehingga untuk selanjutnya bagi masyarakat penting untuk mempertimbangkan pemilihan pemimpin, karena pemimpin yang tegas dan paham mengenai penataan ruang tidak akan mnecederai ketentuan rencana tata kota yang telah diatur. Pemerintah yang teguh pendirian dengan tegas menegakkan penataan ruang sesuai dengan RTRWK tidak akan tergoyahkan walaupun kekuatan pasar tinggi pada permintaan kebutuhan kondominium.

\footnotetext{
${ }^{52}$ Koefisien Dasar Hijau (KDH) adalah angka presentase perbandingan antara luas seluruh ruang terbuka di luar bangunan gedung yang diperuntukkan bagi pertamanan/penghijauan dan luas tanah perpetakan/daerah perencanaan yang dikuasai sesuai rencana tata ruang dan rencana tata bangunan lingkungan. Dalam Peraturan Menteri Pekerjaan Umum Nomor: 05/PRT/M/2008 tentang Pedoman Penyediaan dan Pemanfaatan Ruang Terbuka Hijau di Kawasan Perkotaan, Lampiran, hlm.2

${ }^{53}$ KOMPAS,Ridwan Kamil Bongkar 1.200 M Persegi Lahan Parkir di Mal PVJ, Edisi 08 Januari 2015, http://regional.kompas.com/read/2015/01/08/13412351/Ridwan.Kamil.Bongkar.1.200.Meter. Persegi.Lahan.Parkir.di.Mal.PVJ. terakhir diakses pada tanggal 7 Agustus 2017.
} 


\section{Daftar Pustaka}

Buku:

Henry Campbell Black, M.A, Black's Law Dictionary, Revised Fourth Edition by Publisher's Editorial Staff, ST. Paul, Minn, West Publishing Co, 1968.

Candra Kusuma, Penelitian Interdisipliner Tentang Hukum, Seri Hukum dan Keadilan Sosial, Epistema Institute, Depok, 2013.

Hadi Sabari Yunus, Struktur Tata Ruang Kota, Pustaka Pelajar, Yogyakarta, 1999. Juniarso Ridwan dan Achmad Sodik, Hukum Tata Ruang Dalam Konsep Kebijakan Otonomi Daerah, Nuansa, Bandung, 2007.

M. Daud Silalahi, Hukum Lingkungan Dalam Sistem Penegakan Hukum Lingkungan Indonesia, Alumni, Bandung, 2001.

Pusat Bahasa Departemen Pendidikan Nasional, Kamus Bahasa Indonesia, Jakarta, 2008.

Sulistiowati Irianto, Jan Michele Otto, Sebastiaan Pompe, Adriaan W. Bedner, Jacqueline Vel, Suzan Stoler, dan Julia Arnscheidt, Kajian Sosio-Legal, Seri Unsur-Unsur Penyusun Bangunan Negara Hukum, Penerjemah Tristam Moelyono, Pustaka Larasan, Jakarta: Universitas Indonesia, Universitas Leiden, Universitas Groningen, 2012.

\section{Peraturan Perundang-undangan:}

Undang-Undang Dasar Negara Republik Indonesia Tahun 1945

Undang-Undang Nomor 16 tahun 1985 tentang Rumah Susun LN 1985/75; TLN No. 3318

Undang-Undang RI Nomor 26 Tahun 2007 tentang Penataan Ruang, L.N.R.I. Tahun 2007 Nomor 68

Undang-Undang RI Nomor 32 Tahun 2009 tentang Perlindungan dan Pengelolaan Lingkungan Hidup, L.N.R.I, Tahun 2009 Nomor 140

Undang-Undang RI Nomor 20 Tahun 2011 tentang Rumah Susun

Peraturan Pemerintah Nomor 4 tahun 1988 tentang Rumah Susun

Peraturan Pemerintah RI Nomor 27 Tahun 2012 tentang Izin Lingkungan, L.N.R.I Tahun 2012 Nomor 48

Peraturan Menteri Pekerjaan Umum No.24/PRT/M/2007 tentang Pedoman Teknis Izin Mendirikan Bangunan Gedung

Instruksi Menteri Dalam Negeri Nomor: 30 tahun 1985 tentang Penegakan Hukum/ Peraturan Dalam Rangka Pengelolaan Daerah Perkotaan

Peraturan Menteri Dalam Negeri Nomor: 2 tahun 1987 tentang Pedoman Penyusunan Rencana Kota

Peraturan Menteri Dalam Negeri Nomor 7 tahun 1986 tentang Penetapan Batas Wilayah Kota di Seluruh Indonesia

Peraturan Menteri Pekerjaan Umum Nomor: 05/PRT/M/2008 tentang Pedoman Penyediaan dan Pemanfaatan Ruang Terbuka Hijau di Kawasan Perkotaan

Peraturan Daerah Kota Bandung No. 12 Tahun 2011 tentang Penyelenggaraan, Retibusi Izin Mendirikan Bangunan dan Retribusi Penggantian Biaya Cetak Peta 
Peraturan Daerah Kota Bandung Nomor: 18 Tahun 2011 tentang Rencana Tata Ruang Wilayah Kota Bandung Tahun 2011-2031, Lembaran Daerah Kota Bandung Tahun 2011 Nomor 18

Peraturan Daerah Provinsi Jawa Barat Nomor 2 Tahun 2016 tentang Pedoman Pengendalian Kawasan Bandung Utara sebagai Kawasan Strategis Provinsi Jawa Barat, Lembaran Daerah Provinsi Jawa Barat Tahun 2016 Nomor 2 Seri E

\section{Jurnal Publikasi dan Makalah}

Arie S.Hutagalung, Sistem Kondominium Indonesia: Implikasi dan Manfaatnya bagi Developer/Properti Owner. (Makalah Program Pendidikan Lanjutan Ilmu Hukum Bidang Konsultan Hukum dan Kepengacaraan, FH-UI), Jakarta.

Abdurrahman, Pembangunan Berkelanjutan Dalam Pengelolaan Sumber Daya Alam Indonesia, makalah disampaikan pada: Seminar Pembangunan Hukum Nasional VII Tema Penegakan Hukum Dalam Era Pembangunan Berkelanjutan, diselenggarakan oleh Badan Pembinaan Hukum Nasional, Departemen Kehakiman dan Hak Asasi Manusia RI, Denpasar, 14-18 Juli 2003.

Daud Silalahi, Pembangunan Berkelanjutan Dalam Rangka Pengelolaan (Termasuk Perlindungan) Sumber Daya Alam Yang Berbasis Pembangunan Sosisal dan Ekonomi, makalah disampaikan pada: Seminar Pembangunan Hukum Nasional VII Tema Penegakan Hukum Dalam Era Pembangunan Berkelanjutan, diselenggarakan oleh Badan Pembinaan Hukum Nasional, Departemen Kehakiman dan Hak Asasi Manusia RI, Denpasar, 14-18 Juli 2003.

Donald L. Elliott, Sistem Perijinan Gangguan Sebuah Laporan Tentang Pengendalian Kekacauan, didukung oleh United States Agency for International Development (USAID), Juli, 2008.

Hariyanto dan Tukidi, Konsep Pengembangan Wilayah dan Penataan Ruang Indonesia Di Era Otonomi Daerah, Jurnal Geografi, FIS UNNES, Vol 4 No.1 Januari 2007.

I Wayan Parsa, Laporan Akhir Tim Pengkajian Hukum Tentang Penegakan Hukum Penataan Ruang Dalam Kerangka Otonomi Daerah, Badan Pembinaan Hukum Nasional Kementerian Hukum dan Hak Asasi Manusia R.I, Jakarta, 2014. http://www.bphn.go.id/data/documents/laporan_lengkap.pdf terakhir diunduh pada tanggal 17 Oktober 2017

Jonathan M. Harris, Basic Principles of Sustainable Development, Global Development and Environment Institute working paper 00-04, Tufts University Medford MA 02155, USA, June 2000

Rahmat Saleh, Studi Empiris Ketepatan Waktu Pelaporan Keuangan Perusahaan Manufaktur di Bursa Efek Jakarta, Simposium Nasional Akuntansi VII, Bali. p : 897-910, 2004

Siska Lestari, Vecky A.J Masinambow, dan Mauna Th. B Maramis, Pengaruh Jumlah Penduduk dan Pendapatan Perkapita Terhadap Penerimaan Pajak Restoran di Kota Manado, Jurnal Berkala Ilmiah Efisiensi, Volume 16 No. 02 Tahun 2016, Fakultas Ekonomi dan Bisnis, Universitas Sam Ratulangi 
Manado,.

https://ejournal.unsrat.ac.id/index.php/jbie/article/viewFile/12404/119

77 terakhir di unduh pada tanggal 30 Agustus 2017.

Tom R. Tyler, Why People Obey the Law, Yale University Press, New Haven and London, 1990. http://www.psych.nyu.edu/tyler/lab/Chapters_1-4.pdf terakhir di unduh pada tanggal 30 Agustus 2017.

\section{Sumber lain:}

Asep Warlan Yusuf, Wewenang Pemerintah Dalam Penataan Ruang (Suatu Model Pendekatan Sistem), Disertasi, Universitas Indonesia, Fakultas Hukum Program Pascasarjana, Jakarta, 2002.

, Bahan Kuliah Hukum Perizinan dalam Bisnis, Program

Pascasarjana Ilmu Hukum Universitas Katolik Parahyangan, Bandung, 1999

Herlambang P. Wiratraman, "Penelitian Sosio-Legal dan Konsekuensi

Metodologisnya",

https://herlambangperdana.files.wordpress.com/2008/06/penelitian-

sosio-legal-dalam-tun.pdf terakhir diunduh pada tanggal 19 Juni 2017.

Ketut Wikantika, Ashwin Ismail dan Akhmad Riqqi, Bandung Utara Nasibmu Kini.

Departemen Teknik Geodesi ITB, www.Pikiranrakyat.com edisi Kamis 7 April 2005. Terakhir diakses pada tanggal 26 Agustus 2017.

KOMPAS,Ridwan Kamil Bongkar 1.200 M Persegi Lahan Parkir di Mal PVJ, Edisi 08 Januari 2015, terakhir diakses pada tanggal 7 Agustus 2017. http://regional.kompas.com/read/2015/01/08/13412351/Ridwan.Kamil. Bongkar.1.200.Meter.Persegi.Lahan.Parkir.di.Mal.PVJ

Revisi Kedua Rencana Kerja Pembangunan Daerah (RKPD) Kota Bandung tahun 2014, https://ppid.bandung.go.id/wpcontent/uploads/2016/09/RKPD_2014.pdf terakhir diunduh pada tanggal 26 Agustus 2017.

Site Plan Kondominium La Grande Merdeka, Gambar terakhir diunggah pada tanggal 23 Agustus 2017

https://www.google.co.id/search?q=site+plan+la+grande+merdeka\&sourc $\mathrm{e}=\mathrm{lnms} \& \mathrm{tbm}=\mathrm{isch} \& \mathrm{sa}=\mathrm{X} \& \mathrm{ved}=0$ ahUKEwilsfqdqezVAhURT48KHXs3DosQ AUICigB

Tempo, Izin Hotel Pullman Bandung Harus Ditinjau Ulang, https://nasional.tempo.co/read/562037/izin-hotel-pullman-bandung-harusditinjau-ulang terakhir diakses tanggal 17 Oktober 2017

Wikipedia, tentang Gedung Sate, http://id.wikipedia.org/wiki/Gedung_Sate terakhir diakses pada tanggal 26 Agustus 2017.

Zubair Butudoka, Evaluasi Pemanfaatan Ruang dan Struktur Tata Ruang Wilayah Kabupaten Tolitoli, SMARTek, terakhir diunduh pada tanggal 7 Agustus 2017. http://download.portalgaruda.org/article.php?article=10630\&val=750 